\title{
Stress of Nurses during the COVID-19 Pandemic: A Literature Review
}

\author{
Gunawan $^{1}$, Yuly Peristiowati ${ }^{2}$, Agusta Dian Ellina ${ }^{3}$ \\ 1,2,3 Institute of Health Sciences of Strada Indonesia \\ Email: gunganinglakipadada@gmail.com
}

\begin{abstract}
The COVID-19 pandemic is caused by the Severe Acute Respiratory Syndrome Coronavirus 2 (SARS-Cov-2), has caused a total of 1,531,005 people in Indonesia confirmed positive for COVID-19 and 42,000 people died. The increasing number of COVID-19 cases in Indonesia has made nurses stress as front-liner. This study aims to identify the description of stress in nurses. This study is a systematic literature review by identifying cross-sectional study, published in 2019-2021, in English and Indonesian, and full-text. The electronic database that used was Google Scholar with the keywords "Nurses" AND "Stress" AND "COVID-19". The results obtained 10 articles that related to stress in nurses and factors that caused it. All of studies stated that nurses were stress from mild to severe. Demographic factors that caused stress include age, gender, education level, having children, working status, and years of services. Meanwhile, situational factors were the inconvenience of continuous and strict use a personal protective equipment, being in isolation room, lack of understanding in treating COVID-19 patients, fear of being infected and transmitting the virus to family, and homesickness. An adaptive coping mechanism is needed to reduce stress levels for nurses as the front line in the COVID-19 pandemic.
\end{abstract}

Keywords: Nurses, Stress, and COVID-19.

\section{A. INTRODUCTION}

The COVID-19 pandemic is caused by the Severe Acute Respiratory Syndrome Coronavirus 2 (SARS-Cov-2), the first occurred in Wuhan, China, in early December 2019 (Sepulveda-Loyola et al., 2020). It has spread to Indonesia in March 2020, a total of 1,531,005 people confirmed positive for COVID-19 and 42,000 people died (Kesiapsiagaan Menghadapi Infeksi COVID-19, 2021).

The increasing number of COVID-19 cases in Indonesia has made nurses difficult as front-liner. COVID-19 patients require prophylactic measures to prevent or contain the spread of the virus to other patients: donning protective garments, specific decontamination procedures, isolated areas (Lucchini, Lozzo, \& Bambi, 2020). All these measures increase nursing workload (Giuliani et al., 2018), not only for the time required of their implementation but also for their organization and management. All of these things needed time, organization, and management for their implementation so the workload of nurses increased (Giuliani et al., 2018). Exhaustion due to workload increased, insufficient personal protective equipment, fear of being infected and infecting other, and feeling powerless to handle the patient's condition made nurses were in a stressful situation (Liu et al., 2020). In addition, perceived stress and excessive workloads in nurses can affect their work engagement and quality of care to COVID-19 patients (Zhang et al., 2020). 
Based on the issues above, researcher was interested to identify stress in nurses during the COVID-19 pandemic by conducting a literature review from Indonesia and other countries.

\section{B. RESEARCH METHODS}

This study was a systematic literature review by identifying all types of articles about stress in nurses during the COVID-19 pandemic. The researcher summarized, analyzed, and synthesized the number of related literature so the hypotheses could be tested and new theories were developed (Xiao \& Watson, 2017). The electronic database that used in this study was Google Scholar.

The researcher limited the years of literature from 2019 to 2021 and a crosssectional study. The keywords used in the literature search were: "Nurses" AND "Stress" AND "COVID-19". The total of 70,900 articles were obtained and 10 articles were selected based on criteria and related to stress in nurses during the COVID-19 pandemic.

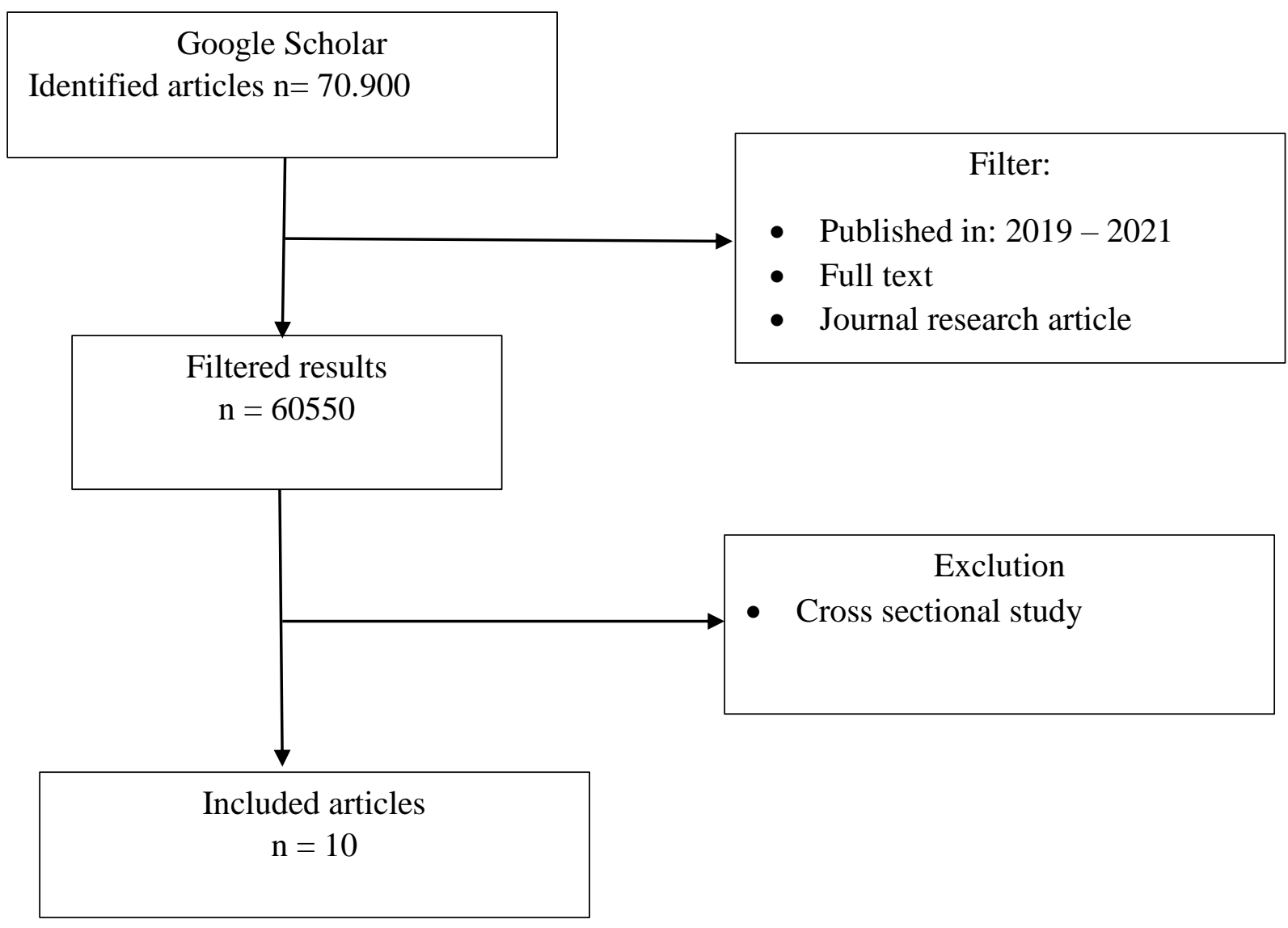

Picture 1. Algorithm of Article Searched 
Table 1. Articles Synthesis

\begin{tabular}{|c|c|c|c|c|c|}
\hline $\begin{array}{l}\text { Writer/ } \\
\text { Country }\end{array}$ & $\begin{array}{l}\text { Research } \\
\text { Objectives }\end{array}$ & $\begin{array}{l}\text { Research } \\
\text { Design }\end{array}$ & Samples & $\begin{array}{l}\text { Variables and } \\
\text { Instruments }\end{array}$ & Results \\
\hline $\begin{array}{l}\text { (Cui et al., } \\
\text { 2021), China }\end{array}$ & $\begin{array}{l}\text { To identify } \\
\text { the } \\
\text { psychologic } \\
\text { al impacts of } \\
\text { COVID-19 } \\
\text { to nurses in } \\
\text { China in } \\
\text { emergency } \\
\text { department } \\
\text { and fever } \\
\text { clinic. }\end{array}$ & $\begin{array}{l}\text { A cross- } \\
\text { sectional }\end{array}$ & $\begin{array}{l}\text { Used snowball } \\
\text { sampling, a total } \\
\text { of } 453 \\
\text { respondents. } \\
\text { Inclusion } \\
\text { criteria: } \\
\text { registered nurse, } \\
\text { work in hospital } \\
\text { in Jiangsu } \\
\text { province, nurses } \\
\text { of emergency } \\
\text { unit and fever } \\
\text { clinic, exposed } \\
\text { to COVID-19 for } \\
\text { more than } 1 \\
\text { month }\end{array}$ & $\begin{array}{l}\text { Variables: } \\
\text { - Anxiety level, } \\
\text { Self-rating } \\
\text { anxiety scale } \\
\text { (SAS) } \\
\text { - Stress, } \\
\text { Perceived } \\
\text { Stress Scale } \\
\text { (PSS) } \\
\text { Coping } \\
\text { mechanism, } \\
\text { Simplified } \\
\text { Coping Style } \\
\text { Questionnaire } \\
\text { (SCSQ) }\end{array}$ & $\begin{array}{l}\text { - As many as } 32.23 \% \\
\text { of nurses were } \\
\text { stress in } \\
\text { emergency unit } \\
\text { and fever clinic } \\
\text { - Stress risk factors: } \\
\text { regret being a } \\
\text { nurse, not } \\
\text { receiving } \\
\text { emergency } \\
\text { protection training, } \\
\text { fear of infecting } \\
\text { families, excessive } \\
\text { night shifts. }\end{array}$ \\
\hline $\begin{array}{l}\text { (Oktovin, } \\
\text { Basit, \& Peni., } \\
\text { 2021), } \\
\text { Indonesia }\end{array}$ & $\begin{array}{l}\text { To identify } \\
\text { the } \\
\text { phenomeno } \\
\mathrm{n} \text { that } \\
\text { related to } \\
\text { psychologic } \\
\text { al stress in } \\
\text { Indonesian } \\
\text { nurses } \\
\text { during the } \\
\text { COVID-19 } \\
\text { pandemic }\end{array}$ & $\begin{array}{l}\text { A cross } \\
\text { sectional }\end{array}$ & $\begin{array}{l}\text { Used non } \\
\text { probability } \\
\text { sampling and } \\
\text { convenience } \\
\text { sampling, a total } \\
\text { of } 157 \text { samples. } \\
\text { Inclusion } \\
\text { criteria: nurses } \\
\text { working in the } \\
\text { hospital, public } \\
\text { health care, } \\
\text { polyclinic and } \\
\text { the other of } \\
\text { health care } \\
\text { facilities, } \\
\text { minimum level } \\
\text { of education is } \\
\text { diploma of } \\
\text { nursing, willing } \\
\text { to fill out a } \\
\text { questionnaire in } \\
\text { google form. } \\
\text { Exclusion } \\
\text { criteria: nurses } \\
\text { who worker in } \\
\text { structural and } \\
\text { did not face the } \\
\text { patient directly }\end{array}$ & $\begin{array}{l}\text { Variables: } \\
\text { sources of stress for } \\
\text { nurses in work, } \\
\text { stress reactions of } \\
\text { nurses and stress } \\
\text { control performed } \\
\text { by nurses, the } \\
\text { questionnaire was } \\
\text { compiled by the } \\
\text { researcher }\end{array}$ & 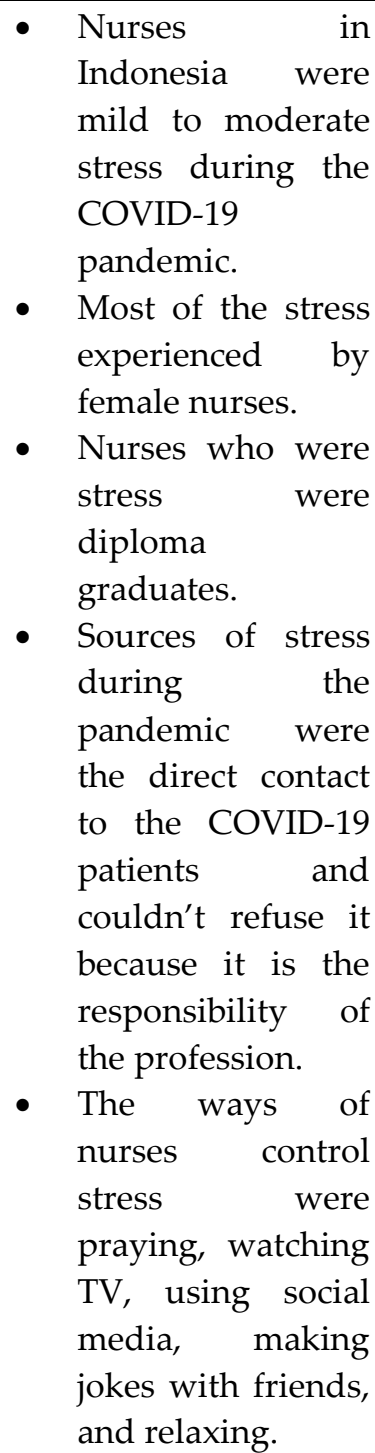 \\
\hline
\end{tabular}




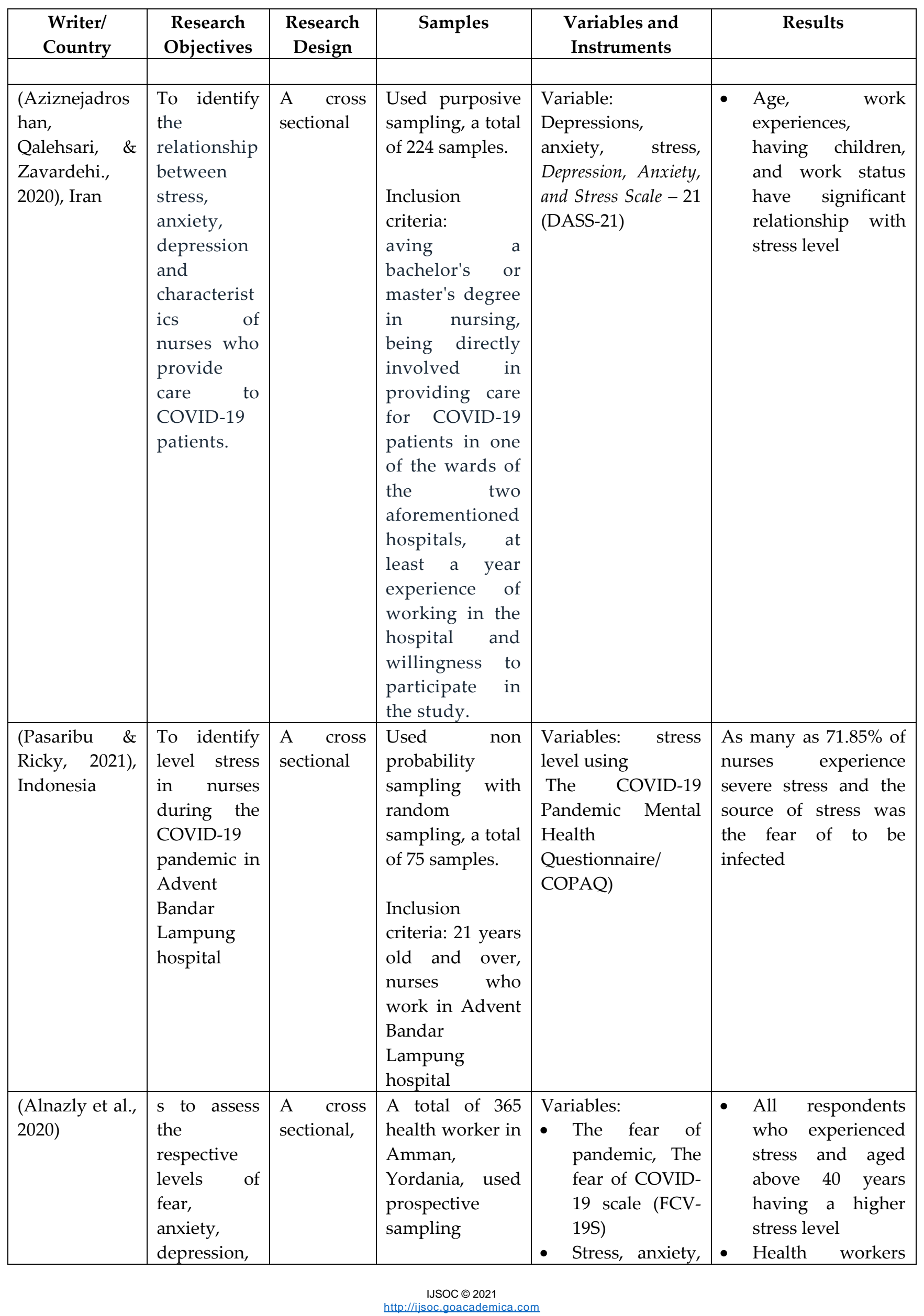




\begin{tabular}{|c|c|c|c|c|c|}
\hline $\begin{array}{l}\text { Writer/ } \\
\text { Country }\end{array}$ & $\begin{array}{l}\text { Research } \\
\text { Objectives }\end{array}$ & $\begin{array}{l}\text { Research } \\
\text { Design }\end{array}$ & Samples & $\begin{array}{l}\text { Variables and } \\
\text { Instruments }\end{array}$ & Results \\
\hline & $\begin{array}{l}\text { stress, social } \\
\text { support, } \\
\text { and the } \\
\text { associated } \\
\text { factors, } \\
\text { experienced } \\
\text { by } \\
\text { Jordanian } \\
\text { health-care } \\
\text { workers } \\
\text { during the } \\
\text { COVID-19 } \\
\text { Pandemic. }\end{array}$ & & 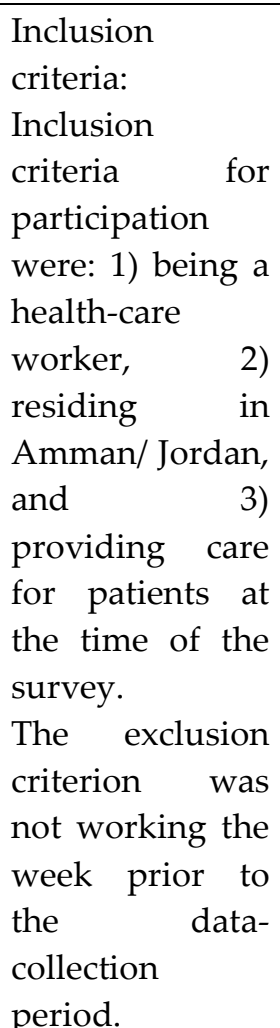 & $\begin{array}{l}\text { depression } \\
\text { level, The } \\
\text { Depression, } \\
\text { Anxiety, Stress } \\
\text { Scale (DASS) } \\
\text { - Perception of } \\
\text { adequate social } \\
\text { support from } \\
\text { family and } \\
\text { friends, and } \\
\text { others, The } \\
\text { Multidimensiona } \\
\text { l Scale of } \\
\text { Perceived Social } \\
\text { Support } \\
\text { (MSPSS) }\end{array}$ & $\begin{array}{lr}\text { feel they receive } & \text { social } \\
\text { high during } \\
\text { support docial } \\
\text { pandemic } \\
\text { - Clinical experience } \\
\text { and have } \\
\text { supports low } \\
\text { positive and lo } \\
\text { significant } \\
\text { correlation with } \\
\text { fear, depression, } \\
\text { anxiety, and stress, } \\
\text { r<0.20 }\end{array}$ \\
\hline $\begin{array}{l}\text { (Musu \& } \\
\text { Saelan, 2021), } \\
\text { Indonesia }\end{array}$ & $\begin{array}{l}\text { To identify } \\
\text { the } \\
\text { description } \\
\text { of stress in } \\
\text { emergency } \\
\text { during the } \\
\text { COVID-19 } \\
\text { pandemic in } \\
\text { Brayat } \\
\text { Minulya } \\
\text { Surakarta } \\
\text { hospital }\end{array}$ & $\begin{array}{l}\text { A cross } \\
\text { sectional }\end{array}$ & $\begin{array}{l}\text { Used total } \\
\text { sampling, a total } \\
\text { of } 20 \text { samples }\end{array}$ & $\begin{array}{l}\text { Variables: level of } \\
\text { work related stress }\end{array}$ & $\begin{array}{l}\text { As many as } 75 \% \text { of } \\
\text { nurses experience } \\
\text { severe stress } \\
\text { Factors that affect } \\
\text { stress: gender, } \\
\text { education level, } \\
\text { marital status, years of } \\
\text { service } \\
\text { Cause of stress: the } \\
\text { large of workload, the } \\
\text { use of personal } \\
\text { protective equipment, } \\
\text { and the number of the } \\
\text { COVID-19 patients }\end{array}$ \\
\hline $\begin{array}{l}\text { (Zhang et al., } \\
\text { 2020), China }\end{array}$ & $\begin{array}{l}\text { To identify } \\
\text { stressors } \\
\text { and burnout } \\
\text { among } \\
\text { frontline } \\
\text { nurses } \\
\text { caring for } \\
\text { COVID-19 } \\
\text { patients in } \\
\text { Wuhan and } \\
\text { Shanghai } \\
\text { and to } \\
\text { explore }\end{array}$ & $\begin{array}{l}\text { A cross } \\
\text { sectional }\end{array}$ & $\begin{array}{l}\text { Used prospective } \\
\text { sampling, a total } \\
\text { of } 110 \text { samples } \\
\text { Inclusion } \\
\text { criteria: } \\
\text { Participants had } \\
\text { worked on the } \\
\text { frontline for } \\
\text { more than } 1 \\
\text { month, and all } \\
\text { participants } \\
\text { cared for severe }\end{array}$ & $\begin{array}{l}\text { Variables } \\
\text { - Stressor, coping } \\
\text { mechanism, } \\
\text { and effective } \\
\text { support } \\
\text { measurement, } \\
\text { using COVID- } \\
19 \\
\text { questionnaire } \\
\text { adopted from } \\
\text { psychological } \\
\text { impacts of } \\
\text { SARS }\end{array}$ & 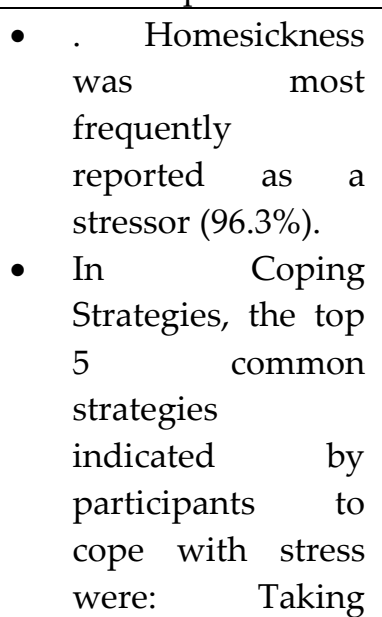 \\
\hline
\end{tabular}




\begin{tabular}{|c|c|c|c|c|c|}
\hline $\begin{array}{l}\text { Writer/ } \\
\text { Country }\end{array}$ & $\begin{array}{l}\text { Research } \\
\text { Objectives }\end{array}$ & $\begin{array}{l}\text { Research } \\
\text { Design }\end{array}$ & Samples & $\begin{array}{l}\text { Variables and } \\
\text { Instruments }\end{array}$ & Results \\
\hline & $\begin{array}{l}\text { perceived } \\
\text { effective } \\
\text { morale } \\
\text { support } \\
\text { strategies. }\end{array}$ & & $\begin{array}{l}\text { and critically ill } \\
\text { COVID-19 } \\
\text { patients. }\end{array}$ & $\begin{array}{l}\text { Burnout, } \\
\text { Maslach } \\
\text { Burnout } \\
\text { Inventory }\end{array}$ & $\begin{array}{l}\text { preventive } \\
\text { measures; Actively } \\
\text { learning about } \\
\text { COVID19; } \\
\text { Actively learning } \\
\text { professional } \\
\text { knowledge; } \\
\text { Adjusting attitude } \\
\text { and facing the } \\
\text { COVID-19 } \\
\text { epidemic r } \\
\text { positively; and } \\
\text { Chatting with } \\
\text { family and friends } \\
\text { The top five } \\
\text { ranked } \\
\text { effective suppost } \\
\text { measures r to } \\
\text { reduce stress as } \\
\text { perceived by the } \\
\text { study participants } \\
\text { were: Support } \\
\text { from supervisors; } \\
\text { Sufficient material } \\
\text { supply; Allowance } \\
\text { provided r by } \\
\text { government; } \\
\text { instruction } \\
\text { treatment on } \\
\text { procedures; and } \\
\text { Adequate r } \\
\text { knowledge } \\
\text { COVID-19 of }\end{array}$ \\
\hline $\begin{array}{l}\text { (Puspitasari, } \\
\text { Suprayitno, \& } \\
\text { Bustami, 2021) }\end{array}$ & $\begin{array}{l}\text { To identify } \\
\text { stress level } \\
\text { in nurses } \\
\text { who work in } \\
\text { emergency } \\
\text { unit }\end{array}$ & $\begin{array}{l}\text { A cross } \\
\text { sectional }\end{array}$ & $\begin{array}{l}\text { Used total } \\
\text { sampling, a total } \\
\text { of } 22 \text { samples. }\end{array}$ & $\begin{array}{l}\text { Variables: } \\
\text { Stress level, } \\
\text { Depression, anxiety, } \\
\text { stress scales (DASS } \\
42)\end{array}$ & $\begin{array}{l}\text { As many as } 9 \% \text { of } \\
\text { nurses experience } \\
\text { mild stress, } 23 \% \\
\text { moderate stress, } 32 \% \\
\text { severe stress, and } 36 \% \\
\text { very severe stress }\end{array}$ \\
\hline $\begin{array}{l}\text { (Chowdhury } \\
\text { et al., 2021) } \\
\text { Bangladesh }\end{array}$ & $\begin{array}{l}\text { to determine } \\
\text { the effects of } \\
\text { the COVID- } \\
19 \text { pandemic } \\
\text { on the } \\
\text { mental } \\
\text { health of } \\
\text { Bangladeshi } \\
\text { nurses, as }\end{array}$ & $\begin{array}{l}\text { A cross } \\
\text { sectional }\end{array}$ & $\begin{array}{l}\text { A total of } 547 \\
\text { respondents } \\
\text { using } \\
\text { convenience } \\
\text { sampling }\end{array}$ & $\begin{array}{l}\text { Variables: } \\
\text { Mental health, The } \\
\text { Depression Anxiety } \\
\text { Stress Scale (DASS- } \\
21 \text { ) and Impact of } \\
\text { Event Scale-Revised } \\
\text { (IES-R) }\end{array}$ & $\begin{array}{ll}\text { - } & 41.7 \% \text { nurses } \\
\text { experience stress } \\
\text { - } & \text { Nurses with } \\
\text { lower education } \\
\text { level experience } \\
\text { less psychological } \\
\text { impact from the } \\
\text { COVID-19, had } \\
\text { lower DASS }\end{array}$ \\
\hline
\end{tabular}




\begin{tabular}{|c|c|c|c|c|c|}
\hline $\begin{array}{l}\text { Writer/ } \\
\text { Country }\end{array}$ & $\begin{array}{l}\text { Research } \\
\text { Objectives }\end{array}$ & $\begin{array}{l}\text { Research } \\
\text { Design }\end{array}$ & Samples & $\begin{array}{l}\text { Variables and } \\
\text { Instruments }\end{array}$ & Results \\
\hline & $\begin{array}{l}\text { well as the } \\
\text { relationship } \\
\text { between } \\
\text { occupationa } \\
1 \text { factors and } \\
\text { mental } \\
\text { health } \\
\text { symptoms. }\end{array}$ & & & & $\begin{array}{l}\text { score, and lower } \\
\text { mental distress } \\
\text { than higher } \\
\text { education level } \\
\text { - There is no } \\
\text { significant } \\
\text { relationship } \\
\text { between } \\
\text { psychological } \\
\text { conditions due to } \\
\text { the COVID-19 } \\
\text { and work } \\
\text { position }\end{array}$ \\
\hline $\begin{array}{l}\text { (Muliantono } \\
\text { et al., 2021) } \\
\text { Indonesia }\end{array}$ & $\begin{array}{l}\text { To identify } \\
\text { psychologic } \\
\text { al response } \\
\text { in nurses } \\
\text { during the } \\
\text { COVID-19 } \\
\text { pandemic in } \\
\text { Indonesia }\end{array}$ & $\begin{array}{l}\text { A cross } \\
\text { sectional }\end{array}$ & $\begin{array}{lr}\text { A total of } 535 \\
\text { nurses who } \\
\text { work in } 119 \\
\text { hospitals of } 24 \\
\text { provinces in } \\
\text { Indonesia using } \\
\text { purposive } \\
\text { sampling }\end{array}$ & $\begin{array}{l}\text { Variables: } \\
\text { psychological } \\
\text { response } \\
\text {, Depression, anxiety, } \\
\text { stress scales (DASS } \\
42 \text { ) }\end{array}$ & $\begin{array}{l}\text { - All respondents } \\
\text { experience } \\
\text { symptoms of mild } \\
\text { anxiety, stress, and } \\
\text { depression every } \\
\text { day } \\
\text { The reasons for } \\
\text { nurses } \\
\text { experiencing } \\
\text { psychological } \\
\text { distress: } \\
\text { insufficient of } \\
\text { understanding } \\
\text { about virus, risk } \\
\text { exposure } \\
\text { patients, lack of } \\
\text { prevention, } \\
\text { prolonged } \\
\text { workload } \\
\text { The psychological } \\
\text { conditions } \\
\text { depends } \\
\text { workplace unit } \\
\end{array}$ \\
\hline
\end{tabular}

\section{RESULT AND DISCUSSION}

From the literature review, it was found that research conducted by Puspitasari, Suprayitno, \& Bustami (2021), 9\% of nurses were in mild stress, 23\% moderate stress, 32\% severe stres, and 35\% very severe stress. Research conducted by Cui et al (2021) on nurses in China, identified as many as $32.23 \%$ of nurses were stress with risk factors: regret for choosing nurses as their profession, did not receive emergency protection training, fear of infecting families, and more night shifts. Meanwhile, in a study by Aziznejadroshan, Qalehsari, \& Zavardehi (2020) in Iran, it was stated that nurses' stress levels had a significant relationship with age, work experience, having children, and working status. This is almost the same as the 
research by Musu \& Saelan (2021) in Indonesia, that 75\% of nurses were stress and the factors were gender, level of education, marital status, and work status. Chowdhury et al (2021) also explained that stress in nurses was related to education level and task unit, but not related to position.

Several studies revealed the causes of stress in nurses during the COVID-19 pandemic. Research conducted by Musu \& Saelan (2021) stated that causes of stress were the excessive workload, the use of personal protective equipment which is very strict, and the number of patients confirmed positive of COVID-19. Research by Pasaribu \& Ricky (2021) in Indonesia added that as many as $71.85 \%$ of nurses were in severe stress and the cause was the fear of being infected. According to Muliantono et al. (2021), the reasons of stress in nurses were insufficient understanding of the virus, the risk of exposure to the COVID-19 patients, lack of prevention, and prolonged excessive workload. Meanwhile, according to Zhang et al (2020) in China, homesickness was the most reported stressor as many as $96.3 \%$ of nurses.

The way nurses deal with stress was also obtained from the literature. According to Oktovin, Basit, \& Peni (2021) in Indonesia, the ways nurses control stress include worship, watched TV, used social media, made jokes with friends, and relaxed. Meanwhile, according to Alnazly et al. (202), nurses' coping strategies in dealing with stress were taking preventive measures, actively learn professional knowledge, and adjust attitudes and face the pandemic positively.

Nurse is one of the most stressful job in the world. Stress in nurses is defined as physical and emotional reactions that occur when nurses' abilities and resources imbalance with demands and requests of their work (Baye et al., 2020). The total of 130 professions that can cause mental health problems, the U.S. The Occupational Safety and Health Institute placed the nursing at 27th position, with a higher level of stress compared to other health worker (Elahi, Mohammadi, \& Khoshknab, 2016). In the COVID-19 pandemic, the stress in nurses has increased even more. Some literatures stated that all nurses in hospitals have experienced stress, ranging from mild t severe (Puspitasari, Suprayitno, \& Bustami, 2021; Cuit et al., 2021; Musu \& Saelan, 2021).

Several studies have identified stressors for nurses during the COVID-19 pandemic based on their demographics. Some also identified stressors based on situational factors. Based on demographics, the factors that caused stress in nurses were age, gender, educational level, having children, working status, and years of service (Qalehsari \& Zavardehi, 2020; Musu \& Saelan, 2021). According to Alnazly et al. (2020), aged less than 40 years tend to have higher stress level. In addition, gender also affected stress where women were twice as susceptible to stress as men (Wilson et al., 2020). Nurses with lower level of educational were less psychological impact from the COVID-19 pandemic, had lower DASS scores, and lower mental distress than the higher education (Chowdhury et al., 2021). Nurses with longer years of service have more clinical experience, making it easier to adapt to patients care, 
especially during a pandemic like this. Clinical experience had a positive correlation and weak significance with stress (Alnazly et al., 2020).

Having direct contact with the COVID-19 patients was a situational factor causing stress in nurses. The discomfort of continuous and tight use of personal protective equipment, being in an isolation room, lack of understanding in the care of the COVID-19 patients were major stressor for nurses (Wang et al., 2020). Even though they have used complete personal protective equipment, the nurses were still worried that they would be infected and transmit the virus to their families (Wang et al., 2020). Therefore, nurses in charge of caring for the COVID-19 patients would be given time to self-isolate in a separate place from their family. This made nurses spend longer without seeing their families so homesickness was also a source of stress in nurses (Zhang et al., 2020).

Work-related stress has been recognized as a major challenge for the nursing profession worldwide and has negative emotional, physical, and psychological impacts in nurses (Baye et al., 2020). Stress reduces immunity and making nurses more vulnerable to the COVID-19 (Simionescu, Pellegrini, \& Bordea, 2021). Therefore, adaptive coping mechanism are neede to help reduce stress in nurses. Coping is defined as thoughts and behaviors that are carried out to manage internal and external stressful situations (Algorani \& Gupta, 2021). Some nurses thought that praying, watching TV, using social media, making jokes with friends, relaxing, actively learning about the COVID-19, and adjusting attitudes and dealing with the pandemic positively can be used as effective coping (Oktovin, Basit, \& Peni, 2021; Alnazly et al., 2020).

\section{CONCLUSION}

From the literature review, all nurses were stress ranging from mild to severe during the COVID-19 pandemic. Stress was caused by demographic and situational factors. Based on demographic factors include age, gender, education level, having children, and years of service. Meanwhile, situational factors were the inconvenience of continuous and strict use of personal protective equipment, being in an isolation room, lack of understanding in treating the COVID-19 patients, fear of being infected and transmitting the virus to the family, and homesickness. An adaptive coping mechanism is needed to reduce stress level in nurses.

\section{REFERENCES}

1. Akbar, R. E.; Elahi, N.; Mohammadi, E.; Khoshknab, M. F. (2016). What strategies do the nurses apply to cope with job stress?: A qualitative study. Glob. J. Health Sci., 8, 55.

2. Algorani EB, Gupta V. Coping Mechanisms. [Updated 2021 May 3]. In: StatPearls [Internet]. Treasure Island (FL): StatPearls Publishing; 2021 Jan-. Available from: https://www.ncbi.nlm.nih.gov/books/NBK559031/

3. Alnazly et al. (2020). Anxiety, depression, stress, fear, and social supporting during COVID-19 pandemic among Jordanian healthcare workers, PLoS ONE, 
16(3). https://doi.org/10.1371/journal. pone.0247679

4. Aziznejadroshan, P., Qalehsari, M., \& Zavardehi, F. (2020). Stress, anxiety, depression among nurses caring for COVID-19 patients in babol, iran: a logestic regression. Research Square, 1-26. https://doi.org/10.21203/rs.3.rs-98099/v1

5. Baye Y, Demeke T, Birhan N, Semahegn A, Birhanu S (2020) Nurses' workrelated stress and associated factors in governmental hospitals in Harar, Eastern Ethiopia: A cross-sectional study. PLoS ONE 15(8): e0236782. https://doi.org/ 10.1371/journal.pone.0236782

6. Chowdhury et al. (2021). Mental health symptoms among the nurses of Bangladesh during the COVID-19 pandemic. Middle East Current Psychiatry, 28(23), 1-8. https://doi.org/10.1186/s43045-021-00103-x

7. Cui et al. (2021). Impact of COVID-19 on anxiety, stress, and coping style in nurses in emergency departments and fever clinics: a cross-sectional survey. Risk Management Healthcare Policy, 14, 585-594. http://doi.org/10.2147/RMHP.S289782

8. Giuliani, E., Lionte, G., Ferri, P., Barbieri, A., (2018). The burden of not-weighted factors - Nursing workload in a medical Intensive Care Unit. Intensive Crit. Care Nurs. 47, 98-101. https://doi.org/10.1016/j.iccn.2018.02.009.

9. Kesiapsiagaan Menghadapi Infeksi COVID-19. (2021). Kementrian Kesehatan Republik Indonesia. https://www.kemkes.go.id/article/view/20012900002/Kesiapsiagaanmenghadapi-Infeksi-Novel-Coronavirus.html

10. Liu, S.; Lithopoulos, A.; Zhang, C.Q.; Garcia-Barrera, M.A.; Rhodes, R.E. Personality and perceived stress during COVID-19 pandemic: Testing the mediating role of perceived threat and efficacy. Personal. Individ. Differ. 2021, $168,110351$.

11. Lucchini, A., Lozzo, P., Bambi, S., (2020). New issues in nursing management during the COVID-19 pandemic in Italy. Am. J. Crit. Care 29 (4), e92-e93. https://doi. org/10.4037/ajcc2020937.

12. Muliantono et al. (2021). Psychological responses among Indonesian nurses in the outbreak of the COVID-19 pandemic. JNC, 4(2), 98-103.

13. Musu, E., Murharyati, A., \& Saelan. (2021). Gambaran stres kerja perawat IGD di masa pandemi COVID-19 di rumah sakit surakarta. Jurnal Gawat Darurat, 3(1), 110.

14. Pasaribu, P., \& Ricky, D. (2021). Tingkat stres perawat terkait isu COVID-19. Jurnal Penelitian Perawat Profesional, 3(2), 287-294

15. Puspitasari, D., Suprayitno, E., \& Bustami. (2021). Tingkat stres kerja perawat instalasi gawat darurat pada masa pandemi COVID-19. Wiraraja Medika: Jurnal Kesehatan, 11(1), 25-29.

16. Oktovin., Basit, M., \& Peni, M. (2021). Psychological stress of nurses during the COVID-19 $\quad$ pandemic. Life Science, 256-267. https://doi.org/10.18502/kls.v6i1.8613

17. Sepúlveda-Loyola, W., Ganz, F., Maciel, R. P. T., Lopes, R. D. S., Negri, P. S., 
Solorza, E. M., Caro, H. G., \& Probst, V. S. (2020). Social participation is associated with better functionality, health status and educational level in elderly women. Brazilian Journal of Development, 6(4), 20690-20701. https://doi.org/10.34117/bjdv6n4-299

18. Simionescu, M., Pellegrini, A., \& Bordea, E. (2021). The effect of COVID-19 pandemic on stress vulnerability of nursing students according to labour market status. Healthcare, 9, 633. https:// doi.org/10.3390/healthcare9060633.

19. Wang, H.; Liu, Y.; Hu, K.; Zhang, M.; Du, M.; Huang, H.; Yue, X. Healthcare workers' stress when caring for COVID-19 patients: An altruistic perspective. Nurs. Ethics 2020, 27, 1490-1500

20. Wilson, W.; Raj, J.P.; Rao, S.; Ghiya, M.; Nedungalaparambil, N.M.; Mundra, H.; Mathew, R. Prevalence and predictors of stress, anxiety, and depression among healthcare workers managing COVID-19 pandemic in India: A nationwide observational study. Indian J. Psychol. Med. 2020, 42, 353-358.

21. Xiao, Y., \& Watson, M. (2017). Guidance on conducting a systematic literature review. SAGE Journals, 39(1), 93-112. https://doi.org/10.1177/0739456X17723971

22. Zhang et al. (2020). Influence of perceived stress and workload on work engagement in front-line nurses during COVID-19 pandemic. Journal of Clinical Nursing, 30, 1584-1595. https://doi/epdf/10.1111/jocn.15707. 